Authors: Jan Burek, Paweł Sułkowicz, Robert Babiarz

Title of article: „Szlifowanie wzdłużne wałków o małej sztywności z korekcją toru ruchu ściernicy” (“Traverse grinding of lowstiffness shafts with the use of a grinding wheel's path correction")

Mechanik, Vol. 91, No. 8-9 (2018): pages 741-743

DOI: https://doi.org/10.17814/mechanik.2018.8-9.120

\title{
Traverse grinding of low-stiffness shafts with the use of a grinding wheel's path correction
}

\author{
Szlifowanie wzdłużne wałków o małej sztywności \\ z korekcją toru ruchu ściernicy
}

\section{JAN BUREK \\ PAWEK SUKKOWICZ \\ ROBERT BABIARZ *}

This paper presents a method of increasing the shape and dimensional accuracy of low-stiffness shafts manufactured in traverse grinding process. In order to achieve that, grinding force measurement was used. It allowed to calculate such a correction of a grinding wheel's path, that allowed to decrease dimensional and shape errors of grinded workpieces.

KEYWORDS: traverse grinding, cylindrical grinding, lowstiffness shafts, cylindricity error

In machines and devices, shafts with low stiffness are commonly used. They find application, among others in the tool, machine, automotive and aerospace industries as well as in precision mechanics. These objects are characterized by a disproportionate overall dimensions and low stiffness in specific directions and cross-sections.

The low stiffness shafts include those in which the ratio of shaft length to its diameter is greater than 10. These parts usually have high requirements as to surface quality, shape accuracy and dimensions [1, 2].

Low stiffness shafts in industrial practice are usually machined in the grinding process as a final shaping operation. The specificity of machining this type of elements makes it difficult to obtain the required parameters of dimensional and shape accuracy and surface quality. The grinding processes are disturbed by many factors, such as: large shaft deformations, stiffness of machine components, changes in temperature, vibrations, chips or changes in machining properties of the grinding wheel [3].

The main factors affecting the dimensional and shape accuracy of traverse grinded low stiffness parts are the stiffness of the workpieces as well as that of the machine tool components [4].

The least rigid elements of the machine tool - tool workpiece system for traverse grinding of the low stiffness shafts are usually the centers of the headstock and the tailstock, as well as the workpiece. Depending on the geometry of the workpiece, these elements can determine over $90 \%$ - the pliability of the entire system [4].

The elastic displacement of the workpiece and the centers of the headstock and tailstock are shown in fig. 1 .

\footnotetext{
* Dr hab. inż Jan Burek prof. PRz (jburek@prz.edu.pl), mgr inż. Paweł Sułkowicz (sulkowicz@prz.edu.pl), dr inż. Robert Babiarz (robertb@prz.edu.pl) _ Katedra Technik Wytwarzania i Automatyzacji, Wydział Budowy Maszyn i Lotnictwa Politechniki Rzeszowskiej
}

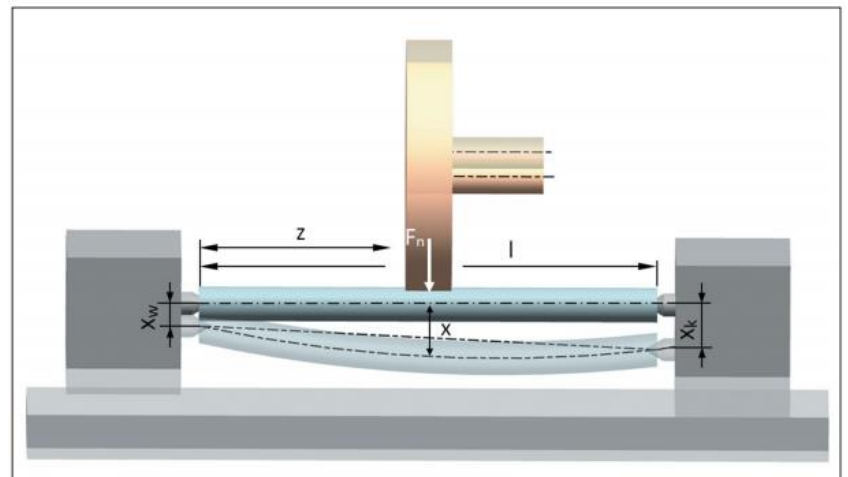

Fig. 1. Elastic displacement of the workpiece and the centers of the headstock $\left(x_{\mathrm{w}}\right)$ and tailstock $\left(x_{\mathrm{k}}\right)$

The total value of the elastic displacement of the workpiece at any point during traverse grinding can be approximated by the equation:

$$
x=x_{1}+x_{2}+x_{3}
$$

where: $x_{1}$ - value of deflection of the workpiece at the point of application of force, $x_{2}$ - displacement of the workpiece due to the pliability of the headstock center, $x_{3}$. displacement of the workpiece due to the pliability of the tailstock's center.

These displacements can be determined using the following relationships:

$$
\begin{gathered}
x_{1}=\frac{F_{\mathrm{n}} \cdot z^{2} \cdot(l-z)^{2}}{3 \cdot E \cdot I \cdot l} \\
x_{2}=\left(1-\frac{z}{l}\right)^{2} \cdot \frac{F_{\mathrm{n}}}{k_{\mathrm{w}}} \\
x_{3}=\left(\frac{z}{l}\right)^{2} \cdot \frac{F_{\mathrm{n}}}{k_{\mathrm{k}}}
\end{gathered}
$$

where: $F_{\mathrm{n}}$ - normal component of the grinding force, $I$ - shaft length, $z$ - position of the grinding wheel in contact with the workpiece, $E$ - Young's modulus, I - moment of inertia of the circular cross-section, $k_{\mathrm{w}}$ - stiffness of the headstock center, $k_{k}$ - stiffness of the tailstock center. 
The total value of the displacement will therefore be:

$$
\begin{aligned}
x\left(F_{\mathrm{n}}, z\right)= & \frac{F_{\mathrm{n}} \cdot z^{2} \cdot(l-z)^{2}}{3 \cdot E \cdot I \cdot l}+\left(\frac{z}{l}\right)^{2} \cdot \frac{F_{\mathrm{n}}}{k_{\mathrm{w}}}+ \\
& +\left(1-\frac{z}{l}\right)^{2} \cdot \frac{F_{\mathrm{n}}}{k_{\mathrm{k}}}
\end{aligned}
$$

The elastic displacement of the machine tool - tool workpiece system elements during grinding results in changes of the grinding depth on the length of the grinded shaft, which consequently leads to dimensional errors and cylindricity errors of the ground parts $[5,6]$.

From dependence (5) it follows that the elastic displacement varies depending on the place of contact between the grinding wheel and the workpiece and the value of the normal grinding force component.

The existing methods of increasing the accuracy of grounded parts with low stiffness, including the use of movable steadies, require high technical expenditure. For this reason, new solutions and methods are being sought for controlling the grinding process, especially in modern CNC controlled grinders, offering the possibility to control the position of the grinding wheel in real time $[4,7]$.

In this context, a new method for controlling the position of the grinding wheel has been proposed. This method allows stabilization of the grinding depth - regardless of the change of the elastic deformation of the workpiece - thanks to the correction of the grinding wheel's path, taking into account the change of machining properties of the grinding wheel during its life span.

\section{Method of stabilizing the grinding depth}

Developed method of grinding with the correction of the grinding wheel's path is based on the control of a grinding wheel infeed (coordinate change $x$ ) depending on its position in the axis of the grounded workpiece ( $\mathrm{z}$ coordinate change) to ensure compensation of the elastic displacement of the workpiece and, as a result, its dimensional and shape accuracy. The diagram of the grinding wheel path control system is shown in fig. 2 .

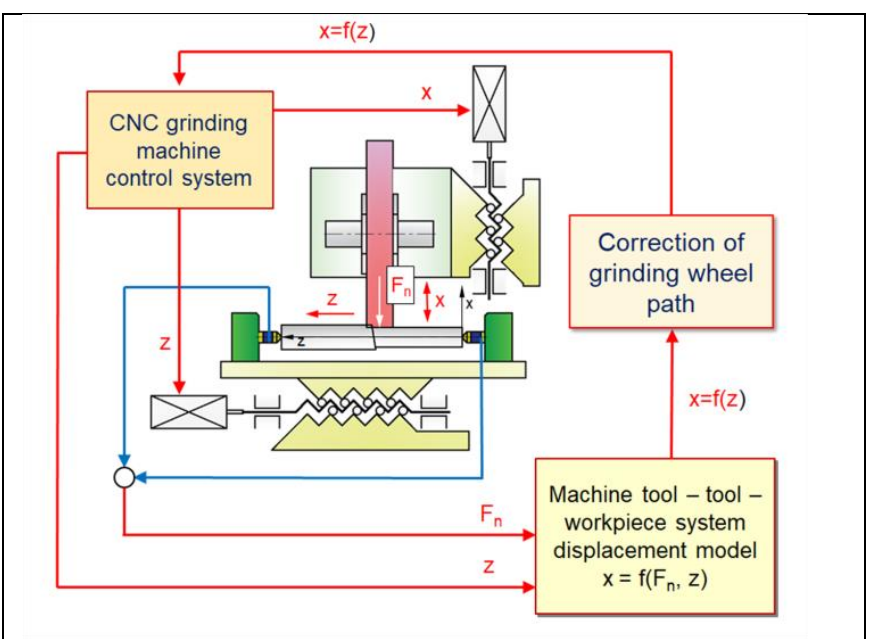

Fig. 2. Control system of the grinding wheel's path

In the grinding wheel path control strategy, the measurement of the normal component of the $F_{\mathrm{n}}$ grinding force is used. During the traverse grinding of the first workpiece (without correction), the normal component $F_{\mathrm{n}}$ of the grinding force is measured. On the basis of the recorded force, the value of the elastic displacement of the workpiece (resulting from its deflection and displacement of the machine tool components) is calculated depending on the point of contact of the grinding wheel with the workpiece during grinding ( $z$ coordinate change).

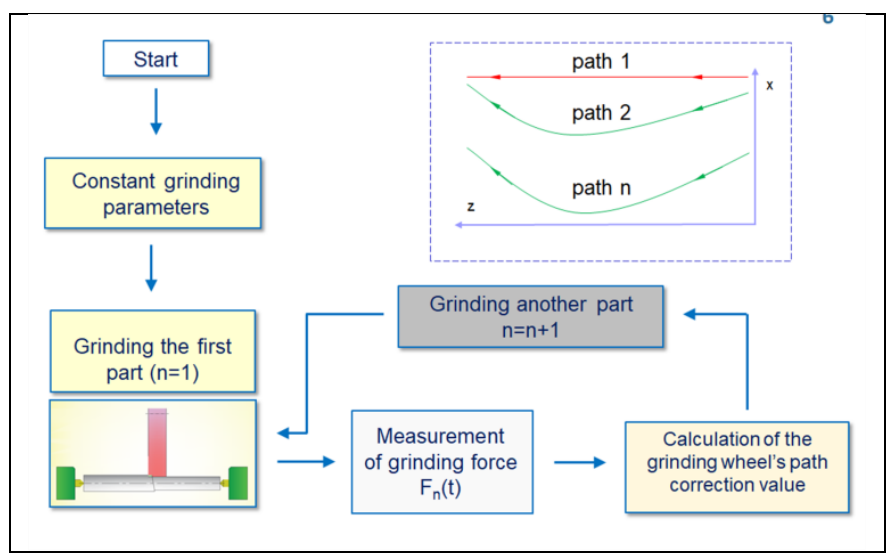

Fig. 3. Grinding algorithm with the correction of the grinding wheel's path

On this basis, a program is created to control the path of the grinding wheel, which is implemented into the machine tool control system and enables grinding with path correction.

For each subsequent part, a new grinding wheel's path is generated, taking into account the change of machining properties of the grinding wheel based on measurement of the changing force $F_{\mathrm{n}}$. The grinding algorithm with the correction of the grinding wheel's path is shown in fig. 3 .

\section{Test conditions}

The test stand was built on the basis of a three-axis CNC shaft grinding machine RS $600 \mathrm{C}$ from Geibel \& Hotz. Two three-component piezoelectric dynamometers from Kistler type $9601 \mathrm{~A}$ were mounted in the centers of the grinding machine (fig. 4).

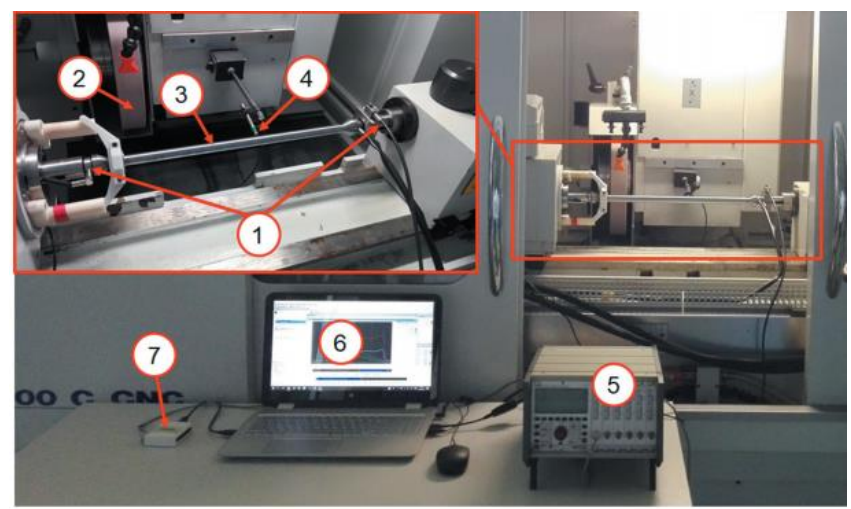

Fig. 4. Test stand: 1 - dynamometers, 2 - grinding wheel, 3 workpiece, 4 - inductive sensor for cylindricity measurement, 5 amplifier, 6 - computer, 7 - A/D converter

During the experimental tests, the test workpieces with different diameters were ground in single pass.

In order to compare the effectiveness of the applied method, the grinding process was carried out without correction and with correction of the grinding wheel's path. The grinding conditions are presented in the table.

\section{TABLE. Grinding conditions}

\begin{tabular}{|l|c|}
\hline Type of grinding wheel & M60H12VE01PI-45 \\
\hline Material machined & steel $40 \mathrm{H}$ \\
\hline Length of workpiece $l, \mathrm{~mm}$ & 400 \\
\hline Diameter of workpiece $d, \mathrm{~mm}$ & $16,18,20,22,24$ \\
\hline Peripheral speed of the grinding wheel $v_{\mathrm{s}}, \mathrm{m} / \mathrm{s}$ & 35 \\
\hline Peripheral speed of the workpiece $v_{\mathrm{w}}, \mathrm{m} / \mathrm{min}$ & 23 \\
\hline Grinding infeed feed $f_{\mathrm{a}}, \mathrm{mm} / \mathrm{rev}$ & 4 \\
\hline Wheel alignment $a_{\mathrm{e}}, \mathrm{mm}$ & 0,06 \\
\hline
\end{tabular}




\section{Results}

The ground shafts after machining were measured using an inductive sensor mounted on the machine spindle. The measurements were carried out in such a way that the grinding machine table together with the workpiece were moved relative to the inductive sensor on the cylindrical surface along the axis of the workpiece at the velocity $v_{\mathrm{m}}=$ $100 \mathrm{~mm} / \mathrm{min}$. The contour of the machined surface was measured six times every $60^{\circ}$. Fig. 5 presents the profile deviations for a workpiece with diameter $d=16 \mathrm{~mm}$, ground without correction and with correction of wheel's path. It can be noted, that the application of the correction of the grinding wheel's path resulted in a significant improvement of the accuracy of the ground workpiece. For the shaft ground with the correction of the grinding wheel's path, the maximum value of the profile deviation was about $5 \mu \mathrm{m}$, which means more than four times the decrease in its value compared to grinding without correction. In both cases, higher deviations of the profile were recorded on the side of the tailstock's center, which is the result of its lower stiffness compared to the stiffness of the headstock's center.

The values of cylindricity deviations for grinding workpieces depending on the change of their diameter are shown in fig. 6. As can be seen, the application of the correction of the grinding wheel's path caused a significant decrease in the value of cylindricity deviation for all ground parts. The greatest improvement in shape accuracy was obtained in the case of a $16 \mathrm{~mm}$ diameter shaft, for which a decrease in cylindrical deviation of approx. $18 \mu \mathrm{m}$ was noted.

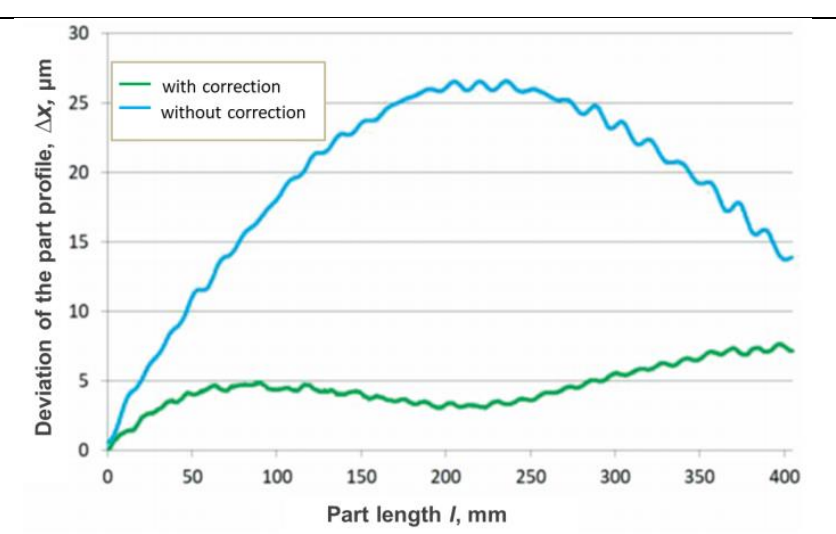

Fig. 5. Deviations of a profile of the workpiece with diameter $d=16$ $\mathrm{mm}$, ground without correction and with correction of the grinding wheel's path

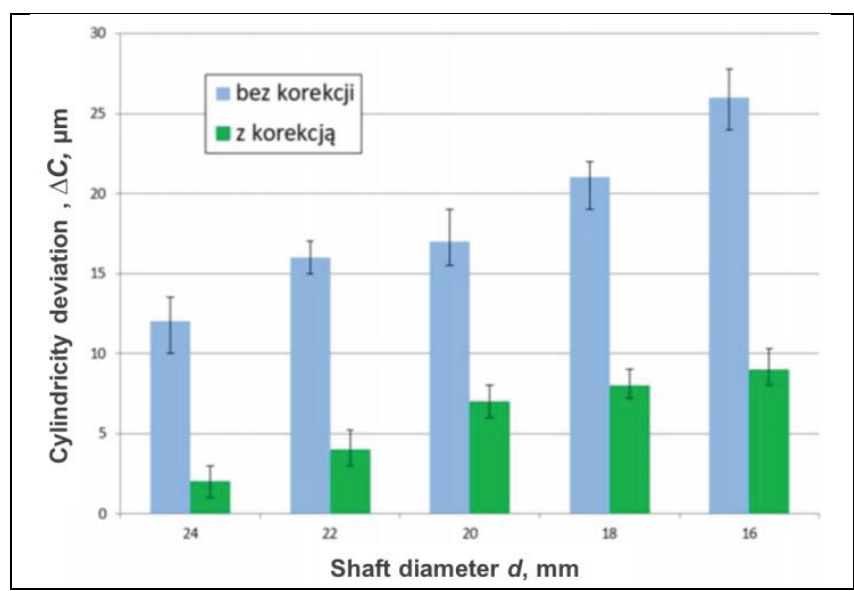

Fig. 6. Deviations of the cylindricity of ground workpieces with correction and without correction of the grinding wheel's path

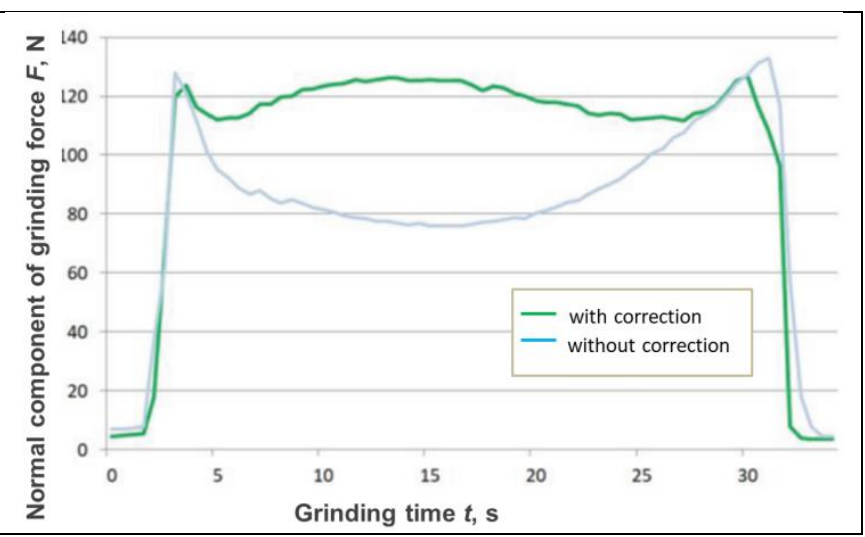

Fig. 7. Variations in the normal component of the $F_{\mathrm{n}}$ grinding force when grinding a shaft with a diameter $d=16 \mathrm{~mm}$ with correction and without correction of the grinding wheel's path

Fig. 7 shows the variations in the value of the normal component of the grinding force during machining of a shaft with diameter $\mathrm{d}=16 \mathrm{~mm}$ with correction and without correction of the grinding wheel's path. The variations of the force $F_{\mathrm{n}}$ for grinding without correction indicates its clear drop resulting from the deflection of the object and, as a result, from a reduction in the depth of cut. For machining with correction of grinding wheel's path, the force values $F_{\mathrm{n}}$ were close to $120 \mathrm{~N}$ in the whole grinding pass.

\section{Conclusions}

In the process of traverse grinding of shafts with low stiffness due to elastic deformation of the machine tool tool - workpiece system, dimensional and shape errors arise. The tests confirmed that the application of the correction of the grinding wheel's path during grinding enables a very large improvement in the accuracy of the machined shafts.

The application of the correction of the grinding wheel's path on the basis of grinding force measurement resulted in several times lower values of cylindricity deviations compared to traditional machining. Due to the high cost of piezoelectric dynamometers, as well as difficulties in their assembly on a machine tool, tests should be carried out to check the applicability - instead of force meters - e.g. an acoustic emission sensor.

Summing up, the traverse grinding method with the correction of the grinding wheel's path improves the accuracy of machined shafts with low stiffness and can be an alternative to multi-pass grinding or grinding with the use of steadies.

\section{REFERENCES}

1. Świć A. „Technologia obróbki wałów o małej sztywności”. Lublin: Wydawnictwo Politechniki Lubelskiej, 2009.

2. Oliveira J., Silva E., Guo C. "Industrial challenges in grinding". CIRP Annals - Manufacturing Technology. 58, 2 (2009): pp. 663-680.

3. Park W., Kim D., Lee S. "Shape prediction during the cylindrical traverse grinding of a slender workpiece". Journal of Materials Processing Technology. 88, 1 (1999): pp. 23-32.

4. Burek J. „Regulacja i nadzorowanie procesu szlifowania wgłębnego walcowych powierzchni zewnętrznych". Rzeszów: Oficyna Wydawnicza Politechniki Rzeszowskiej, 2017.

5. Jianliang G., Rhondi H. "A united model of diametral error in slender bar turning with a follower rest". International Journal of Material Forming. 46, 1 (2006): pp. 1002-1012.

6. Nadolny K. „Klasyfikacja procesów szlifowania jednoprzejściowego". Mechanik. 5-6 (2008): pp. 450-455.

7. Wołos D., Taranenko V., Świć A. „Klasyfikacja metod osiągnięcia niezawodności technologicznej obróbki wałów o małej sztywności”. Przegląd Mechaniczny. 5 (2007): pp. 154155. . 
Translation of scientific articles, their computer composition and publishing them on the website www.mechanik.media.pl by original articles in Polish is a task financed from the funds of the Ministry of Science and Higher Education designated for dissemination of science.

Ministry of Science and Higher Education

Republic of Poland 